\title{
SEJARAH ASUS
}

Nazri Adlaimi

185100047

Fakultas Komputer

nazriadlaimi.student@umitra.ac.id

\begin{abstract}
ASUS, adalah sebuah perusahaan berbasis di Taiwan yang memproduksi komponen komputer seperti papan induk, kartu grafis, dan notebook. Asus belakangan ini mulai memproduksi PDA, Telepon genggam, monitor LCD, tablet dan produk komputer lainnya. Pesaing utamanya termasuk MSI, dan Gigabyte.

Asus pada 2005 menjual papan induk lebih banyak dari perusahaan lainnya, termasuk 30 juta pada 2004. Angka ini termasuk kontrak merek lain. Asus juga memproduksi komponen untuk perusahaan lain, termasuk PS2 Sony dan Applelpod, iBook, dll

ASUS banyak dipilih pengguna karena berani memberikan garansi 2 tahun untuk produk notuytv yang dibuatnya.

Pada tahun 2014 Asus menggandeng PT Dragon Computer \& communication untuk menjadi distributor utama notebook dan tablet di Indonesia dan berhasil menjadi merek nomor satu hingga saat ini (menurut data IDC dan GFK).

Asus yang merupakan perusahaan "Public" telah mendaftar pada lantai Bursa Efek Taiwan dengan kode 2357 dan daftar sekunder di London Stock Exchange dengan kode ASKD.
\end{abstract}

Kata Kunci : Sejarah Asus. 
A. PENDAHULUAN

Setelah sukses dengan kehadiran produk tablet Asus Transformer untuk kalangan menengah ke atas, pada tahun 2013, Asus memperkenalkan Asus MeMO Pad dalam ukuran 7 inch dan 10 inch yang harganya lebih terjangkau. Fitur Asus MeMO Pad yang cukup keren adalah Floating App yang memungkinkan beberapa aplikasi berjalan bersamaan dan semuanya tampak di layar tanpa harus bergantian. Artinya, Anda dapat menonton video sambil browsing, atau sambil mengedit file office yang disediakan di ASUS WebStorage Online Office

\section{B. PEMBAHASAN / STUDI KASUS}

Nama Asus mungkin sudah terdengar sangat familiar di telinga pengguna komputer tanah air termasuk saya sebagai pengguna setianya . Perusahaan asal Taiwan tersebut mengandalkan inovasi untuk tumbuh dan berkembang hingga menjadi raksasa ekonomi seperti sekarang. Inilah sekelumit cerita tentang salah satu pionir ternama di dunia komputer .

Sejarah Singkat

Kisah Asus bermula pada tahun 1989, ketika empat insinyur komputer, yaitu Wayne Hsieh, Ted Hsu, MT Liao dan TH Tung berniat mendirikan perusahaan baru untuk memajukan industri TI di Negara Taiwan. Nama yang mereka pilih adalah "Pegasus" yang diambil dari sebutan untuk makhluk mitos asal Yunani. Pada perkembangannya, nama tersebut dipendekkan menjadi "Asus" agar bisa tampil di urutan awal sesuai alphabet.

Berbeda dengan sekarang, kala itu Asus yang berkantor di sebuah apartemen kecil di Taipei, Taiwan, bergerak di bidang konsultasi komputer dan tidak memproduksi hardware buatan sendiri seperti sekarang ini . Namun, setelah berhasil membuat dan menjual motherboard untuk prosesor Intel 486 pada akhir dekade 80-an, perusahaan ini mulai berkonsentrasi ke konstruksi hardware.

Dalam perjalanannya, perusahaan yang mulai "go public" pada tahun 2005 ini tumbuh semakin pesat. Motherboard Asus terpasang di $29,2 \%$ 
komputer desktop yang terjual sepanjang tahun 2009. Di tahun yang sama Asus membukukan pendapatan senilai USD21,2 miliar. Untuk mengefisiensikan kinerja perusahaan, pada tahun 2007 Asus membagi diri menjadi tiga perusahaan berbeda, yaitu Pegatron (berfokus pada produksi komponen PC dan perangkat OEM), Unihan (manufaktur perangkat nonPC), serta Asus sendiri yang berkonsentrasi penuh pada produksi notebook dan sistem komputer utuh.

Sekilas Cerita Produk Asus

Selama puluhan tahun berkecimpung dalam bisnis hardware komputer, Asus telah menelurkan berbagai macam produk. Saat ini saja terdapat puluhan jenis motherboard yang tersedia. Belum lagi jika menghitung jenis-jenis produk lainnya. Secara keseluruhan, Asus membuat motherboard, graphics card, notebook, netbook, produk networking sever dan workstation, monitor, produk multimedia, optical storage, peripheral,dan aksesoris komputer

Asus juga pernah membuat beberapa CPU cooler, seperti seri Arctic Square yang ditujukan untuk platform socket AM2 dan LGA 775 ini.

Belakangan ini, Asus rajin membuat inovasi perangkat mobile. Dalam bidang tersebut, salah satu produk Asus yang paling iconic adalah Eee PC, komputer portabel dengan ukuran fisik lebih kecil dan berat lebih ringan daripada notebook biasa yang disebut sebagai "netbook". Istilah "netbook" sendiri sebelumnya sudah pernah digunakan oleh salah satu produsen perangkat mobile asal Amerika Serikat. Namun, dalam perkembangannya, istilah tersebut menjadi sebutan umum dan lazim digunakan untuk mengacu pada perangkat mobile sekelas Asus Eee PC yang diperkenalkan pertama kali pada tahun 2007. Tak lama setelah kemunculan Eee PC, banyak produsen lain yang mengikuti langkah asus dan memproduksi perangkat serupa.

Eee PC generasi pertama dilengkapi dengan prosesor Celeron $800 \mathrm{MHz}$, memori $512 \mathrm{MB}$, flash memory untuk storage sebesar $2 \mathrm{~GB}$, serta OS berbasis Linux.

Asus juga memproduksi ponsel, termasuk smartphone bermerk 
Garmin-Asus yang dibuat melalui kerjasama dengan produsen GPS device, Garmin.

Perkembangan hardware komputer buatan Asus juga terus berjalan seiring dengan pengembangan perangkat mobile. Tahun 2006, Asus memperkenalkan seri produk motherboard "Republic of Gamers" yang khusus ditujukan untuk kalangan pemain game komputer. Lini motherboard ini dilengkapi dengan berbagai feature terbaik dari Asus ketika itu, seperti dukungan konfigurasi multiGPU, soundcard SupremeFX, sistem pendingin heatpipe, dan kemampuan overclocking tinggi.

Striker Extreme, salah satu motherboard seri Republic of Gamers pertama dari Asus.

Seri motherboard Republic of Gamers yang terbaru adalah Rampage III Black Edition dengan chipset Intel X58 yang mendukung prosesor-prosesor desktop terkencang saat ini. Asus pun tetap mengikuti perkembangan motherboard mainstream dan menyediakan platform yang sesuai untuk CPU modern, termasuk seri prosesor Sandy Bridge dari Intel. P8Z68-V Pro, motherboard Asus dengan chipset terbaru dari Intel: Z68.

Selain motherboard, salah satu jenis komponen hardware yang menjadi spesialisasi Asus adalah graphics card. Pada pertengahan 1990-an, perusahaan ini memperkenalkan seri graphics card berbasis chip grafis Rage 3D dari ATI. Setelah itu, muncul graphics card Asus yang menggunakan chip grafis dari produsen lain, yaitu NVIDIA, yang sedang mulai naik daun ketika itu. Lini graphics card Asus terus berlanjut hingga sekarang. Produk-produk lain pun, seperti notebook, peripheral jaringan, optical drive, hingga netbook dan smart phone mulai dikembangkan oleh Asus.

Graphics card Asus berbasis chip ATI Rage 3D II dengan interface $\mathrm{PCl}$ (atas) dan NVIDIA Riva 128 dengan interface AGP (bawah), muncul pada paruh kedua dekade 90-an.

Hingga saat ini, Asus terus membuat graphics card dengan chipset ATI (AMD) dan NVIDIA. Beberapa feature khusus, seperti voltage tweak yang memungkinkan modifikasi nilai voltase dan HSF 
DirectCu yang memiliki kemampuan transfer panas lebih baik dar HSF biasa, turut diterapkan di jajaran graphics card high-end buatan produsen ini. Asus pun membuat beberapa graphics card "special edition", seperi seri Mars dan Ares yang dilengkapi dengan chip grafis terkencang pada masanya.

Asus Ares, graphics card dengan dua buah GPU Radeon HD 5870.

Dan untuk "game series" Asus tak mau ketinggalan dengan vendor-vendor besar lainnya . Salah satu yang paling populer saat ini adalah Produk Laptop Game Series "ROG" yang diberi $\begin{array}{lll}\text { nama } & \text { ASUS } & \text { VX7 }\end{array}$ Lamborghini . Nama Lamborghini tak lain terinspirasi oleh pabrikan mobil sport yang eksis dalam penciptaan supercar yang sangat fenomenal. Embel-embel Lamborghini tersebut juga bermaksud untuk mempublikasikan kepada para pecinta game $P C$,bahwa Serie VX7 ini adalah laptop yang sehati untuk para penikmat game PC dunia . Dari sudut-sudut tampilannya VX7 memang tampil elegant dan memberi kesan kokoh dari Logo Lamborghini dan bentuk laptop itu sendiri yang cenderung mirip dengan salah satu mobil fenomenal keluaran Lamborghini .

ASUS juga turut memproduksi beragam komponen untuk perusahaan lain seperti Dell, Falcon Northwest, HewlettPackard dan Apple. Perusahaan yang berpusat di distrik Beitou, Taipei, Taiwan tersebut juga sering menjalin kerjasama dengan perusahaan lain untuk meningkatkan nilai merknya, seperti dengan lamborghini, samsung dan founder technology. Salah satu produk asus yang paling fenomenal adalah accelerator card PhysX yang dirilis pada september 2005 dan Eee PC netbook yang pada tahun 2008 sukses menjadi produk terbaik di asia versi forbes.

ASUS juga memberikan perhatian pada isu lingkungan . Pada tahun 2000 ASUS mengkampanyekan program GREEN ASUS yang meliputi green design, green procurement, green manufacturing dan green service and marketing. Bersama intel dan Tsann Kuen Enterprise Co, ASUS meluncurkan program PC Recycling for Brighter Future dan berhasil mengumpulkan 1.200 PC, notebooks dan monitor yang kemudian di daur ulang untuk disumbangkan ke 122 
sekolah dasar dan sekolah menengah pertama di lima komunitas berbeda.

C. ID SECURITY

QWTD4452377-ASP-

5244107

D. KESIMPULAN

Sekian sekilas sepenggal sejarah berdirinya salah satu perusahan komputer terkemuka yang hingga sampai saat ini masih eksis dan uptodate dalam meluncurkan produk-produk yang berkualitas dan menduduki peringkat pertama sedunia sebagai perangkat dengan kualitas no.1 di dunia komputer .

E. DISKUSI

Pathul:bagaimana sejarah asus selama ini?

Me:sampai dengan saat ini perkembangan produk asus sangat baik dan mampu bersahing dg produk lainnya. Purkon:apa kelebihan rdoduk asus

Me: desain sangat mewah layak nya plagship,kapasitas batrai jumbo di atas rata rata,ketahanan tangguh dengan gorilla glass 6,termurah dengan snapdragon 660

F. REFERENCE

[1] O. M. Febriani and A. S. Putra, "Sistem Informasi Monitoring Inventori Barang Pada Balai Riset Standardisasi Industri Bandar Lampung," J. Inform., vol. 13, no. 1, pp. 90-98, 2014.

[2] A. S. Putra, "Paperplain: Execution Fundamental Create Application With Borland Delphi 7.0 University Of Mitra Indonesia," 2018.

[3] A. S. Putra, "2018 Artikel Struktur Data, Audit Dan Jaringan Komputer," 2018.

[4] A. S. Putra, "ALIAS MANAGER USED IN DATABASE DESKTOP STUDI CASE DB DEMOS."

[5] A. S. Putra, "COMPREHENSIVE SET OF PROFESSIONAL FOR DISTRIBUTE COMPUTING."

[6] A. S. Putra, "DATA ORIENTED RECOGNITION IN BORLAND DELPHI 7.0."

[7] A. S. Putra, "EMBARCADERO DELPHI XE 2 IN GPUPOWERED FIREMONKEY APPLICATION."

[8] A. S. Putra, "HAK ATAS KEKAYAAN INTELEKTUAL DALAM DUNIA TEKNOLOGY BERBASIS INDUSTRI 4.0."

[9] A. S. Putra, "IMPLEMENTASI PERATURAN

PERUNDANGAN UU. NO 31

TAHUN 2000 TENTANG DESAIN INDUSTRI BERBASIS INFORMATION TECHNOLOGY."

[10] A. S. Putra, "IMPLEMENTATION OF PARADOX DBASE."

[11] A. S. Putra, "IMPLEMENTATION OF TRADE SECRET CASE STUDY SAMSUNG MOBILE PHONE."

[12] $A . \quad S$ Putra, 
"IMPLEMENTATION PATENT FOR APPLICATION WEB BASED CASE STUDI WWW. PUBLIKLAMPUNG. COM." [13] A. S. Putra, "IMPLEMENTATION SYSTEM FIRST TO INVENT IN DIGITALLY INDUSTRY."

[14] A. S. Putra, "MANUAL REPORT \& INTEGRATED DEVELOPMENT

ENVIRONMENT BORLAND DELPHI 7.0."

[15] A. S. Putra, "PATENT AS RELEVAN SUPPORT RESEARCH."

[16] A. S. Putra, "PATENT FOR RESEARCH STUDY CASE OF APPLE. Inc."

[17] A. S. Putra, "PATENT PROTECTION FOR APPLICATION INVENT."

[18] A. S. Putra, "QUICK REPORT IN

PROPERTY PROGRAMMING."

[19] A. S. Putra, "REVIEW CIRCUIT LAYOUT COMPONENT REQUIREMENT ON ASUS NOTEBOOK."

[20] A. S. Putra, "REVIEW TRADEMARK PATENT FOR INDUSTRIAL TECHNOLOGY BASED 4.0."

[21] A. S. Putra, "TOOLBAR COMPONENT PALLETTE IN OBJECT ORIENTED PROGRAMMING."

[22] A. S. Putra, "WORKING DIRECTORY SET FOR PARADOX 7."

[23] A. S. Putra, "ZQUERY CONNECTION IMPLEMENTED PROGRAMMING STUDI CASE PT. BANK BCA Tbk."
[24] A. S. Putra, D. R. Aryanti, and I. Hartati, "Metode SAW (Simple Additive Weighting) sebagai Sistem Pendukung Keputusan Guru Berprestasi (Studi Kasus: SMK Global Surya)," in Prosiding Seminar Nasional Darmajaya, 2018, vol. 1, no. 1, pp. 85-97.

[25] A. S. Putra and O. M. Febriani, "Knowledge Management Online Application in PDAM Lampung Province," in Prosiding International conference on Information Technology and Business (ICITB), 2018, pp. 181-187.

[26] A. S. Putra, O. M. Febriani, and B. Bachry, "Implementasi Genetic Fuzzy System Untuk Mengidentifikasi Hasil Curian Kendaraan Bermotor Di Polda Lampung," SIMADA (Jurnal Sist. Inf. dan Manaj. Basis Data), vol. 1, no. 1, pp. 21-30, 2018.

[27] A. S. Putra, H. Sukri, and K. Zuhri, "Sistem Monitoring Realtime Jaringan Irigasi Desa (JIDES) Dengan Konsep Jaringan Sensor Nirkabel," IJEIS (Indonesian J. Electron. Instrum. Syst., vol. 8, no. 2, pp. 221-232.

[28] D. P. Sari, O. M. Febriani, and A. S. Putra, "Perancangan Sistem Informasi SDM Berprestasi pada SD Global Surya," in Prosiding Seminar Nasional Darmajaya, 2018, vol. 1, no. 1, pp. 289-294. 
